\title{
Advanced Biology Notes
}

David Harrison, Ph.D.

Assistant Master, Eton College

\section{Macmillan Education}


(C) David Harrison 1971

All rights reserved. No part of this publication may be reproduced or transmitted, in any form or by any means, without permission.

First published 1967

Reprinted 1969

Second edition 1971

Published by

MACMILLAN EDUCATION LIMITED

Basingstoke and London

The Macmillan Company of Australia Pty Ltd, Melbourne

The Macmillan Company of Canada Ltd, Toronto

St Martin's Press Inc, New York

Companies and representatives

throughout the world

ISBN 978-0-333-00203-2

ISBN 978-1-349-00021-0 (eBook)

DOI 10.1007/978-1-349-00021-0 


\section{List of Contents}

Preface to First Edition

Preface to Second Edition

$\mathbf{v}$

Acknowledgements

Part I THE CELL AND ITS METABOLISM

Structure of cell membranes; the cell wall; structure and activities of the interphase nucleus; nucleic acid structure and replication; protein synthesis; respiratory pathways and energy relationships in the cytoplasm; photophosphorylation.

Part II BIOCHEMICAL DATA

Structures and roles in organisms of proteins, carbohydrates, lipids and steroids; special roles of macro-molecules in relation to Part I.

Part III LEVELS OF ORGANISATION

Organisation in non-cellular organisms: bacteria, viruses, protozoa and protophyta. Organisation in the multicellular body.

Part IV TRANSPORT SYSTEMS IN MULTICELLULAR ORGANISMS

Transport systems in annelids, insects and vertebrates; structure, functions and circulation of blood, lymph. Transport systems in higher plants, translocation and transpiration; root functions.

Part V SYSTEMS OF COORDINATION

Nervous coordination; cephalisation; central and peripheral systems in chordates; the neurone, synapse and sense organs. Hormonal coordination in animals and plants.

\section{Part VI MODES OF NUTRITION}

Saprophytic fungi; nutrition and digestion in protozoans, insects and vertebrates; roles of digestive organs and the liver. Photosynthetic pathways; the chloroplast and the nature of the light energy pathway; products of photosynthesis.

\section{Part VII GAS EXCHANGE}

Modes of gas exchange in micro-organisms; insects; terrestrial vertebrates. Ventilation; control of breathing. Gas exchange in flowering plants.

vi

vii

1 
The contractile vacuole; flame cell; nephridium. The mammalian nephron; urine formation; loop of Henlé; regulatory role of the kidney. Homeostatic systems; regulation of temperature, gas content, $\mathrm{pH}$, solutes and osmotic pressure.

Part IX SUPPORT AND LOCOMOTION

Support in terrestrial plants. Swimming and control of direction in the fish; skeleton of fish and amphibian; skeleton and support in the mammal; skeletal muscle, tone, innervation, coordination and contraction; oxygen debt.

Part X GROWTH AND ASEXUAL REPRODUCTION

Mitosis; growth and reproduction in flowering plants; asexual reproduction in animals; growth and control of ecdysis in insects.

Part XI MODES OF SEXUAL REPRODUCTION

147

Sexual reproduction in thallophytes, mosses, ferns and flowering plants; cross-pollination and fertilisation; seed formation and dispersal; regulators of germination. Reproductive processes in invertebrates; dogfish; frog metamorphosis. Gametogenesis, oestrus, pregnancy and post-natal care of offspring in the mammal.

Part XII OUTLINE OF CLASSICAL GENETICS AND

EVOLUTIONARY PRINCIPLES

Meiosis; Mendel's Laws and experiments; multiple alleles; lethal genes; sex determination and sex linkage. Development of evolutionary theory and its evidence. Genetic basis of evolution, the modern synthesis; the gene pool concept. Maintenance of the integrity of the individual, defences against infection. 


\section{Preface to the First Edition}

Biology Notes is a compendium of biological data designed to aid the student in classwork and revision. In detail its depth conforms to that required by Advanced and Scholarship Levels, University Entrance, and 1st M.B. examinations. In breadth it covers more topics than any single syllabus since different examination boards have selected different combinations of types for study.

Its aim is two-fold. First, it will provide the examination candidate with a framework of relevant, factual information in note form, to which he can add notes from his own observations or reading. Second, it will cut down the time spent in the classroom copying down notes, thus freeing teaching time for explanation, discussion and laboratory work.

Anatomical topics and animal and plant types carry little or no explanation. Diagrams are in simple line form, without shading, labelled from a functional point of view wherever possible. Biochemical and physiological topics have some explanation, since this is inherent in these aspects of the work.

It must be stressed that this book does not set out to be definitive. No experimental evidence is offered and there are few references to original work. Likewise there is no index. Other books admirably approach the subject through reasoned statements and it is to these books that Biology Notes is complementary. 


\section{Preface to the Second Edition}

In the last few years substantial changes have been made in Advanced Level biology syllabuses. These changes reflect the current attitudes of most biological research workers, practitioners and educationists at all levels. Most biologists are agreed that previous syllabuses, based primarily on the study of types, tended to lead to an unbalanced view in which organisms like the dogfish, the frog, the butterfly and the buttercup assumed prominence out of all proportion to their real importance.

Syllabuses based on the study of types also tended to emphasise the differences between organisms, especially between animals and plants. Yet those biological topics which are occupying most of the attention of research workers and which, by and large, students find the most interesting embrace most if not all organisms, plant and animal alike.

With these changes in mind Biology Notes has been completely re-structured. To conform more closely to new syllabuses the book is divided into twelve parts, by topic. Within each topic plant and animal structure and function are dealt with concurrently, where this is relevant, and the 'types' have been omitted. Other material removed from the book include data which bear little relevance to the understanding of principles or functions or organisms, for example 'Types of Fruits, berries, pepos, drupes, etc.' and 'Types of Inflorescence, racemose and cymose, etc.'.

Some topics have been expanded, notably the sections on cellular metabolism, systems of coordination, reproduction and evolution.

Advanced Biology Notes is not about plants and animals, it is about biology. The applicability of the book to the various syllabuses, its aims and its limitations are still the same as those outlined in the preface of the First Edition. The success of the first edition was gratifying and it is hoped that the second edition will prove of still greater service to students and to examination candidates. 


\section{Acknowledgements}

The author and publisher wish to thank the following for permission to reproduce the photographs listed below:

Barnaby's Picture Library pp. 89, 92 (right)

Professor Ruth Bowden p. 141 (lower)

Brian Bracegirdle B.Sc. FRPS FIIP pp. 55 (left and right), 80, 94, 106

Gene Cox pp. 42, 43, 45, 58 (lower), 59, 64 (top), 69, 110 (left), 111, 119, 120, 129, 137, 148, 153, 162 , 163 (upper and lower), 165 (upper), 166, 172, 176, 183, 185

John D. Dodge pp. 8 (lower), 10 (right), 31

Dr P. Echlin p. 165 (lower)

Edinburgh University Press p. 98

Professor H. Fernandez-Moran p. 19 (upper)

M. E. Howard and B. J. K. Tricker from Science of Movement, Mills \& Boon 1967 p. 82

B. E. Juniper pp. 64,112

Dr A. R. Leiberman, Dept. of Anatomy and Embryology, University College of London pp. 10, 19 (upper)

K. R. Lewis and B. John p. 290

Dr D. F. Millington p. 107

Dr E. Mugnaini p. 141

Press Association p. 92 (left)

Allen Ross pp. 186, 203

John Shillcock p. 39

Dr D. S. Skene pp. 25, 202

Dr David S. Smith p. 141 (upper)

James Webb p. 150 (right) 